\title{
Prediking is sinkronisering van God se tyd met die tyd waarin ons leef
}

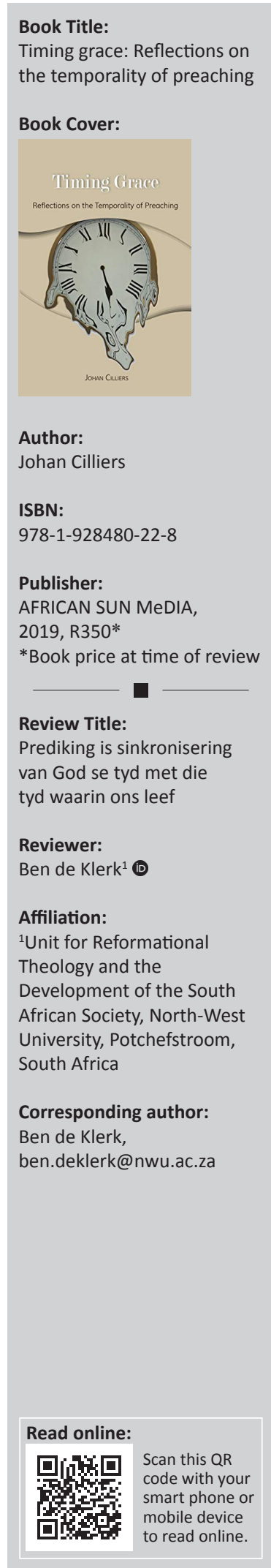

Hierdie boek is 'n opvolg en 'tweeling' van Cilliers se boek van 2016, A space for grace. Dit handel oor tyd en die verhouding tussen prediking en tyd, in verbinding met 'space'. Die skrywer dui aan dat dit uiters moeilik is, feitlik onmoontlik, om die fenomeen van tyd te beskryf. Tog is betroubare prediking 'n kuns om die nou van genade ('now of grace') te preek wat onlosmaaklik met verlede en toekoms verbind is, maar wat tegelyk ook 'n dinamiese gebeure is, gevul met die heerlike teenwoordigheid van God.

In die eerste hoofstuk (Tempus fugit?) dui Cilliers aan dat hy in hierdie boek tyd ook as liniêr beskou, as 'n beweeg van die verlede na die toekoms, en dat tyd vlietend is, altyd aan die beweeg. Verlede en toekoms kan nie van die hede losgemaak word nie. Prediking vind altyd in die hede plaas al kan dit nie sonder die verlede en die toekoms wees nie.

In die daaropvolgende hoofstuk beskryf Cilliers genade as 'n verbygaande stortbui wat nie gestop of beheer kan word nie. Dit val van bo op enigeen, volgens eie tydsberekening. In die prediking vertrou ons dat 'n stortbui van genade sal neerval. Dan beskryf hy die rol van prediking soos volg: 'It is the role of preaching - turning everyday-time into God's time, coming into sinc with the Kairos of the Christ-event - and vice versa' (bl. 34). Sinkronisering is nodig om die evangelietyd van genade te kombineer met die tyd waarin ons lewe. Om dit te kan bereik, is die kuns van improvisasie nodig.

Cilliers stel in die deel oor Mistiming grace dat die verswyging van die krag van die evangelie op 'n gegewe oomblik in die prediking, asook die gebrek aan konfrontering voorbeelde is van mistiming. Prediking is nie bloot om die bybelse teks te herhaal nie, maar om 'n uitdagende nuwe woord te spreek wat nodig is om hier en nou gehoor te word. In die hoofstuk oor Interrupting time behandel die skrywer preke van Suid-Afrika se 'interrupters', naamlik Boesak, Tutu en Naudé. Hy gebruik die Heidelbergse metode om hierdie preke op 'n baie interessante wyse te ontleed.

In die hoofstuk oor Wasting time gaan dit oor geleenthede wat verspeel word om die regte tyd vanuit die regte teks oor die regte krisis te preek, byvoorbeeld oor die ekologie wat tans in die brandpunt is. Wat predikers teenoor die verspilling van tyd in elke preekgeleentheid behoort te ervaar, word soos volg deur Cilliers beskryf:

God is present, constantly surprising us with the unexpected twists and turns of 'God's' timing, 'God's' improvisation, 'God's' synchronisation of grace, with and witin the 'times like these', in which we live. (bl. 166)

Die Bybel, so skryf hy in die deel oor Timing the text, praat oor die verlede en die toekoms op so 'n wyse dat die hede as die nóú van die teenwoordigheid van God geopenbaar word. In die slothoofstuk (A timely conclusion) gee hy 'n kort en kragtige beskrywing van prediking: 'Preaching is about the timing of grace, i.e. pre-sencing of the Presence of God in the present' (bl. 225).

Cilliers, self 'n kunstenaar, illustreer met kunswerke en die bespreking daarvan sy argumente en hy konkretiseer met verskeie preke, waarvan sommige sy eie, verskillende aspekte van sy bespreking van 'timing of grace'.

Timing grace is 'n waardevolle bydrae tot die wetenskap van die Homiletiek. Dit lig nuwe fasette van God se tyd in die hede uit, nie slegs vir die Homiletiek nie, maar ook vir die

How to cite this book review: De Klerk, B., 2020, 'Prediking is sinkronisering van God se tyd met die tyd waarin ons leef', In die Skriflig 54(1), a2555. https://doi.org/10.4102/ids.v54i1.2555

Copyright: ( 2020 . The Authors. Licensee: AOSIS. This work is licensed under the Creative Commons Attribution License. 
Teologie in die algemeen. Die boek het waarde vir die ernstige navorser in Homiletiek wat deur hierdie en die 'tweelingboek', Space for grace, geïnspireer kan word om nuwe aspekte van die vakgebied na te speur. Die geskrif het ook genoeg stof vir predikers wat erns wil maak met die spesifieke tyd van die teks, asook (en veral) met die tyd (tydstip) waarin die prediker en die hoorders op daardie oomblik leef. Meer nog: vir predikers wat teks, hoorder en die teenwoordigheid van God in daardie moment biddend saam wil ontdek. 